Article

\title{
Exergetic, Economic and Exergo-Environmental Analysis of Bottoming Power Cycles Operating with $\mathrm{CO}_{2}$-Based Binary Mixture
}

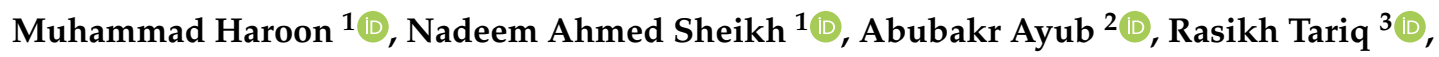 \\ Farooq Sher ${ }^{4}$ (D), Aklilu Tesfamichael Baheta ${ }^{5}$ and Muhammad Imran ${ }^{6, *(D)}$ \\ 1 Department of Mechanical Engineering, International Islamic University Islamabad (IIUI), \\ Islamabad 44000, Pakistan; haroon.msme49@iiu.edu.pk (M.H.); ndahmed@gmail.com (N.A.S.) \\ 2 Department of Mechanical and Industrial Engineering, Universita Degli Studi Di Brescia, via Branze 38, \\ 25121 Brescia, Italy; a.ayub@unibs.it \\ 3 Facultad de Ingenieria, Universidad Autonoma de Yucatan, Av. Industrias No Contaminantes por Anillo \\ Periferico Norte, Apdo., Postal 150 Merida, Mérida 97310, Yucatan, Mexico; rasikhtariq@gmail.com \\ 4 School of Mechanical, Aerospace and Automotive Engineering, Faculty of Engineering, \\ Environmental and Computing, Coventry University, Coventry CV1 5FB, UK; Farooq.Sher@coventry.ac.uk \\ 5 Mechanical Engineering Department, Universiti Teknologi PETRONAS, \\ Bandar Seri Iskandar 32610, Perak, Malaysia; aklilu.baheta@utp.edu.my \\ 6 School of Mechanical, Biomedical and Design Engineering, College of Engineering and Applied Sciences, \\ Aston University, Aston Triangle, Birmingham B4 7ET, UK \\ * Correspondence: m.imran12@aston.ac.uk
}

Received: 27 August 2020; Accepted: 26 September 2020; Published: 29 September 2020

check for updates

\begin{abstract}
This study focused on investigating the bottoming power cycles operating with $\mathrm{CO}_{2}$-based binary mixture, taking into account exergetic, economic and exergo-environmental impact indices. The main intent is to assess the benefits of employing a $\mathrm{CO}_{2}$-based mixture working fluid in closed Brayton bottoming power cycles in comparison with pure $\mathrm{CO}_{2}$ working fluid. Firstly, selection criteria for the choice of suitable additive compound for $\mathrm{CO}_{2}$-based binary mixture is delineated and the composition of the binary mixture is decided based on required cycle minimum temperature. The decided $\mathrm{CO}_{2}-\mathrm{C}_{7} \mathrm{H}_{8}$ binary mixture with a 0.9 mole fraction of $\mathrm{CO}_{2}$ is analyzed in two cycle configurations: Simple regenerative cycle (SRC) and Partial heating cycle (PHC). Comparative analysis among two configurations with selected working fluid are carried out. Thermodynamic analyses at varying cycle pressure ratio shows that cycle with $\mathrm{CO}_{2}-\mathrm{C}_{7} \mathrm{H}_{8}$ mixture shows maximum power output and exergy efficiency at rather higher cycle pressure ratio compared to pure $\mathrm{CO}_{2}$ power cycles. $\mathrm{PHC}$ with $\mathrm{CO}_{2}-\mathrm{C}_{7} \mathrm{H}_{8}$ mixture shows $28.68 \%$ increment in exergy efficiency with the levelized cost of electricity (LCOE) $21.62 \%$ higher than pure $\mathrm{CO}_{2} \mathrm{PHC}$. Whereas, SRC with $\mathrm{CO}_{2}-\mathrm{C}_{7} \mathrm{H}_{8}$ mixture shows $25.17 \%$ increment in exergy efficiency with $\mathrm{LCOE} 57.14 \%$ higher than pure $\mathrm{CO}_{2} \mathrm{SRC}$. Besides showing lower economic value, cycles with a $\mathrm{CO}_{2}-\mathrm{C}_{7} \mathrm{H}_{8}$ mixture saves larger $\mathrm{CO}_{2}$ emissions and also shows greater exergo-environmental impact improvement and plant sustainability index.
\end{abstract}

Keywords: $\mathrm{CO}_{2}$-based binary mixture; bottoming power cycles; exergetic analysis; $\mathrm{CO}_{2}$ emissions savings; sustainability index; exergo-environmental impact indices

\section{Introduction}

Efficiency in heat to power conversion systems is a global concern. Power-generating systems possessing improved thermodynamic, economic, and environmental performances are a top priority of researchers and manufacturers [1]. One key area for improvement is the waste heat utilization 
and the thermodynamics of such systems, which is getting more attention due to their ability to save energy and improved power generation, resulting in reduced fuel utilization, power production cost, and greenhouse emissions. This is the reason that the amount of power produced along with the type and the cost of technologies used for the recovery of waste heat resources are the essential elements deciding the feasibility of such technologies and resultant energy utilization.

In the past decade, several technologies for energy conversion are being studied, like air Brayton power cycles and organic Rankine power cycles (ORCs) [2-5]. However, ORCs have efficiency constraints when operating using a waste heat source at moderate (relatively higher) bottoming cycle turbine temperatures due to the limitations related to thermal and physical properties of commonly used organic working fluids [6]. In recent times, stringent developments and modifications in supercritical carbon dioxide $\left(\mathrm{S}-\mathrm{CO}_{2}\right)$ Brayton power cycles are observed due to its capacity of achieving higher thermal efficiencies when operating with low to medium range heat sources [7]. In virtue of less corrosive behavior of $\mathrm{CO}_{2}$, it can be used with relatively higher-temperature heat source applications like S- $\mathrm{CO}_{2}$ Brayton power cycles powered by nuclear heat source [8-10] and solar power tower [11,12]. In addition to this, $\mathrm{CO}_{2}$ provides many environmental and thermodynamic benefits, including null ozone depletion potential $(\mathrm{ODP}=0)$ and minimum global warming potential $(\mathrm{GWP}=1) . \mathrm{CO}_{2}$ is non-flammable, non-toxic, chemically inert, inexpensive, and shows low compressibility factor closer to critical point (i.e., $31^{\circ} \mathrm{C}$ and $7.4 \mathrm{MPa}$ ). Several studies are performed on the power production potential of $\mathrm{S}-\mathrm{CO}_{2}$ Brayton power cycles in low- and high-grade waste heat utilization applications $[13,14]$.

As per Köppen Climate classification, the typically densely populated regions of the earth having low precipitation and elevated average ambient temperatures are categorized as BWh zones [15]. Zones such as Riyadh, Dubai, Karachi, and many parts of MENA where the highest ambient temperatures are between 40 and $50{ }^{\circ} \mathrm{C}$ and constitute $12 \%$ of Earth. For higher ambient temperatures, the cycle minimum temperature increases and a clear rise in compressor work and drop in thermal efficiency are observed, as shown in Figure 1 [16].

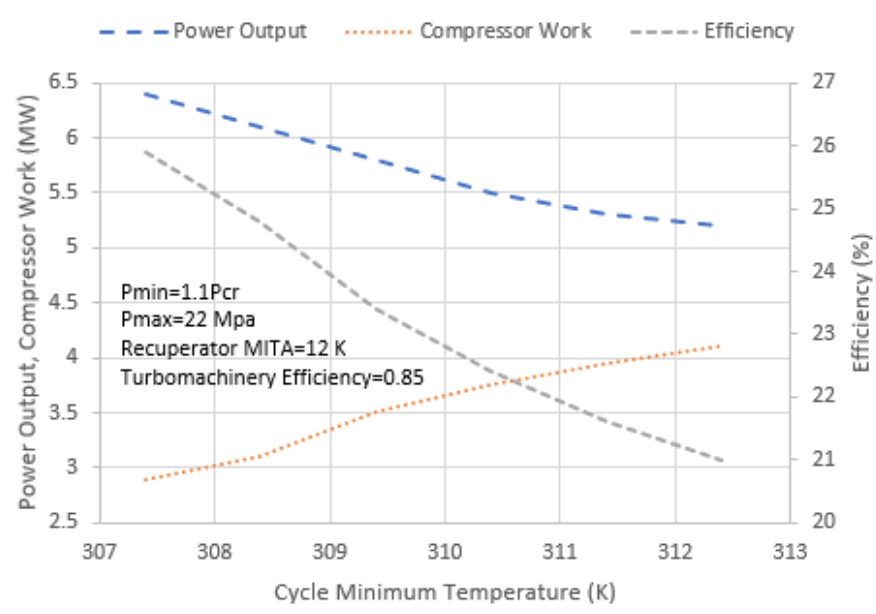

Figure 1. Performance decrement of $\mathrm{S}-\mathrm{CO}_{2}$ Brayton power cycles at higher cycle minimum temperatures.

Therefore, the performance enhancement of $\mathrm{S}-\mathrm{CO}_{2}$ Brayton power cycles in high ambient temperature zones can be achievable by relocating the $\mathrm{CO}_{2}$ critical point to higher temperatures by adding the second working fluid in $\mathrm{CO}_{2}$; this can be done by designing a $\mathrm{CO}_{2}$-based binary mixture [17]. Designing a $\mathrm{CO}_{2}$-based binary mixture can be performed by adding inorganic/organic compounds to relocate the mixture critical point to higher temperatures so that cycle minimum temperature can be matched with higher ambient temperature climatic conditions, especially of BWh zones [18].

Invernizzi et al. [19] analyzed Brayton power cycles powered by different $\mathrm{CO}_{2}$-based binary mixtures as operating fluids. A clear performance improvement in Brayton power cycles operating with $\mathrm{CO}_{2}$-based binary operating mixtures in comparison with pure $\mathrm{S}-\mathrm{CO}_{2}$ Brayton power cycles is observed. Seungjoon et al. [20] investigated the performance of Brayton power cycles for hot ambient 
conditions operating with $\mathrm{CO}_{2}$-based binary mixtures. Authors concluded that power cycles operating with $\mathrm{CO}_{2} /$ toluene and $\mathrm{CO}_{2} / \mathrm{R} 32$ binary mixtures are more efficient as compared to simple $\mathrm{S}-\mathrm{CO}_{2}$ power cycles.

Due to intrinsic characteristics, the research on power cycles powered by $\mathrm{CO}_{2}$-based binary mixtures has been growing in the selection of working fluids and performance optimization of power cycles for both low and high-temperature heat sources [21,22]. The main challenges are the attainment of appropriate thermodynamic efficiencies, selection, and assessment of admixtures for $\mathrm{CO}_{2}$-based binary mixtures suitable for a large span of heat sources. Moreover, recent researches has been done on thermodynamic properties and thermal stability of pure and mixture working fluids [23-25].

Along with thermodynamic aspects, economic and environmental aspects of the power cycles should be considered for comprehensive analysis. Haroon [16] in his thesis performed comparative study and suggested that the $\mathrm{CO}_{2}-\mathrm{C}_{6} \mathrm{~F}_{14}$ mixture is a better option for power generation at higher temperature ambient conditions in comparison with $\mathrm{CO}_{2}-\mathrm{C}_{7} \mathrm{H}_{8}$ mixture because it performs well in terms of exergy efficiency, less plant-specific cost and environmentally benign working fluid. Manzolini et al. [17] adopted $\mathrm{CO}_{2}$-based mixtures to improve the thermal to power conversion efficiency for solar power plants and to minimize the levelized cost of electricity. The higher conversion efficiencies and lower cost results in a 10\% reduction in the levelized cost of electricity with reference to the traditional steam power cycle.

Haroon et al. [26] also conducted a detailed sensitivity analysis for energetic and exergetic efficiencies comparing the simple regenerative and partial heating bottoming power cycles applied to topping gas turbines. The partial heating cycle is suggested as a better option for power production in warm climatic conditions due to better thermodynamic performance, less overall UA, and plant-specific cost. Xia et al. [27] published research on exergo-economic and thermodynamic performances of transcritical power cycles powered by $\mathrm{CO}_{2}$-based binary mixtures. In the case of the low-temperature power cycle, the $\mathrm{CO}_{2} / \mathrm{R} 32$ mixture produces the maximum exergy efficiency of $52.85 \%$ and $\mathrm{CO}_{2} / \mathrm{R} 161$ presented the minimum levelized cost per unit of exergy product of $47.909 \mathrm{USD} / \mathrm{MWh}$. In the case of the high-temperature power cycle, $\mathrm{CO}_{2} / \mathrm{C}_{3} \mathrm{H}_{8}$ presented the minimum levelized cost per unit of exergy product of $29.212 \mathrm{USD} / \mathrm{MWh}$.

The utilization of $\mathrm{CO}_{2}$-based binary mixtures as working fluids in heat to power conversion systems is a possible choice due to the favorable characteristics of $\mathrm{CO}_{2}$ and the enhanced efficiency of $\mathrm{CO}_{2}$ power cycles, as mentioned earlier. It is worth noting that the $\mathrm{CO}_{2}$-based binary mixture comprised of additive compound in an appropriate composition can potentially give benefit to the design a mixture with desirable properties [18].

This study investigates the exergetic, economic, and exergo-environmental performance of two different configurations of bottoming power cycles powered by carbon dioxide-based binary mixture for warm climatic conditions. A detailed literature survey indicates that heat to power conversion systems powered by carbon dioxide-based binary mixture is not explored extensively earlier, especially for warm climatic conditions. Bottoming power cycles hold two challenges: firstly, the achievement of maximum efficiency and secondly transformation to effective work. The exhaust heat of GE-LM2500 medium-scale topping gas turbine is employed as a heat source for the comparative performance analysis of bottoming power cycles. Principal parameters considered as a selection criterion of carbon dioxide-based binary mixture are thermodynamic characteristics, heat source compliance, and HSE (health, safety and environment) properties at the first stage. At the second stage, the thermodynamic properties of the binary mixture are computed, and the reliability of the thermodynamic model is ensured. Then, the parametric analysis is conducted to recommend practical conditions (pressure ratio) for power production. Ultimately, the comparative performance analysis is conducted for power cycles operating with pure carbon dioxide and carbon dioxide-based binary mixture. Lastly, the best performing bottoming power cycle is suggested based on exergetic efficiency, energetic efficiency, exergo-environmental analysis, and $\mathrm{CO}_{2}$ emissions savings. 


\section{Thermodynamic, Economic and Environmental Analysis}

\subsection{Selection of $\mathrm{C}_{7} \mathrm{H}_{8}$ Additive and Properties of $\mathrm{CO}_{2} / \mathrm{C}_{7} \mathrm{H}_{8}$ Binary Mixture}

This study is the extension of a previous study [26], which explored the exergetic performance gain by employing $\mathrm{CO}_{2} / \mathrm{C}_{7} \mathrm{H}_{8}$ binary mixture in $\mathrm{CO}_{2}$ bottoming power plants. In the present study, for the computation of exergetic, economic, and exergo-environmental performance of bottoming power plants powered by pure $\mathrm{CO}_{2}$ and $\mathrm{CO}_{2} / \mathrm{C}_{7} \mathrm{H}_{8}$ binary mixture, the thermodynamic properties of $\mathrm{CO}_{2} / \mathrm{C}_{7} \mathrm{H}_{8}$ binary mixture are employed from the previous study. Thermodynamic and HSE characteristics of pure $\mathrm{CO}_{2}$ and $\mathrm{C}_{7} \mathrm{H}_{8}$ are enclosed in Table 1. Detailed selection criteria for the organic additive in $\mathrm{CO}_{2}$ are presented in the previous study. A comprehensive section namely, "Properties of the binary mixture" including Vapor liquid equilibrium (VLE) diagrams at different temperatures, critical points, and dew and bubble lines at different compositions was already included in the previous study. In this section, the importance of toluene as an additive for designing binary mixture and EOS (equation of state) employed for the computation of thermodynamic properties of $\mathrm{CO}_{2} / \mathrm{C}_{7} \mathrm{H}_{8}$ binary mixture are discussed.

Table 1. Thermodynamic and HSE characteristics of pure $\mathrm{CO}_{2}$ and Toluene.

\begin{tabular}{|c|c|c|c|c|c|c|c|c|}
\hline Fluid & $\begin{array}{c}\text { Molar Mass } \\
(\mathrm{kg} / \mathrm{kmol})\end{array}$ & $\begin{array}{c}P_{c r} \\
\text { (Bars) }\end{array}$ & $T_{c r}\left({ }^{\circ} \mathrm{C}\right)$ & $\begin{array}{c}\text { Thermal Stability } \\
\text { Limit }\left({ }^{\circ} \mathrm{C}\right)\end{array}$ & ODP & GWP & $\begin{array}{c}\text { Auto Ignition } \\
\text { Temperature }\left({ }^{\circ} \mathrm{C}\right)\end{array}$ & Flammability \\
\hline Toluene & 92.14 & 41.08 & 318.6 & 400 & 0 & low & 480 & Yes \\
\hline $\mathrm{CO}_{2}$ & 44.01 & 73.8 & 31.06 & 800 & 0 & Very low & N/A & Not flammable \\
\hline
\end{tabular}

In recent times, the potential of toluene for power generation in ORCs is evaluated for biomass, combustion turbine, and internal combustion engine waste heat utilization applications [28]. Some distinguished properties of toluene are highlighted below:

- The critical point temperature is greater than $\mathrm{CO}_{2}$, which is advantageous for the designing of a binary mixture having a high critical temperature.

- Thermochemically stable up to $400{ }^{\circ} \mathrm{C}$ in static testing carried out within stainless steel loop [23].

- Highly flammable having flash point temperature of $3{ }^{\circ} \mathrm{C}$. Nevertheless, its flammability can be restrained by maintaining the lower mole fraction in binary mixture design.

- Moderately toxic, however, its harmful impacts on humanity may potentially be reduced by using efficient filtration techniques [29].

- Highly compatible with aluminum and stainless steel at low cycle temperatures.

Owing to favorable thermodynamic, health, safety and environment (HSE) properties, toluene is a suitable additive for designing $\mathrm{CO}_{2}$-based working fluid in bottoming power plants.

The EOS employed for pure $\mathrm{CO}_{2}[30,31]$ and $\mathrm{C}_{7} \mathrm{H}_{8}$ [32] are present in the literature. However, for the implementation of $\mathrm{CO}_{2} / \mathrm{C}_{7} \mathrm{H}_{8}$ binary mixture, it is vital to have adequate mixing rules as well as experimental data of thermodynamic properties of binary mixture for the fitting of the relevant equation of state parameters. To avoid the complication in model development, Peng-Robinson EOS is employed in this study for the computation of $\mathrm{CO}_{2} / \mathrm{C}_{7} \mathrm{H}_{8}$ binary mixture thermodynamic properties.

Peng-Robinson EOS is extensively used to investigate the thermodynamic properties of pure and mixed working fluids due to its enhanced predictive capability as compared to other equation of states $[33,34]$. In the present study, all thermodynamic calculations by using Peng-Robinson EOS are performed in the Aspen Plus simulation environment. Aspen Plus computes entropies and enthalpies by calculating the integral of residual functions [35].

\subsection{Energy and Exergy Model}

A medium-scale gas turbine (GE LM2500) [36] is selected as a referral topping loop for bottoming power cycles, due to thermal stability limitation (i.e., $400{ }^{\circ} \mathrm{C}$ ) enforced by toluene. The particulars of the topping loop and exhaust gas component mole fractions are enclosed in Table 2. 
Table 2. Specification of GE-LM2500 topping gas turbine. Adapted from [26].

\begin{tabular}{cccc}
\hline Parameter & Value & \multicolumn{2}{c}{ Exhaust Gas Composition } \\
\hline Power Output & $24.8 \mathrm{MW}$ & Component & Mole Fractions \\
\cline { 3 - 4 } Efficiency & $35.1 \%$ & $\mathrm{CO}_{2}$ & 0.03 \\
Pressure Ratio (P.R) & 19 & Nitrogen & 0.76 \\
$\begin{array}{c}\text { Mass Flow Rate of } \\
\text { exhaust gases (MFR) }\end{array}$ & $71 \mathrm{~kg} / \mathrm{sec}$ & Oxygen & 0.14 \\
$\begin{array}{c}\text { Exhaust gases } \\
\text { Temperature }\left(\mathrm{T}_{\text {exh,in }}\right)\end{array}$ & $798 \mathrm{~K}\left(525^{\circ} \mathrm{C}\right)$ & Water & 0.07 \\
\hline
\end{tabular}

The analysis of the topping loop is not incorporated because this study emphasizes on exergetic, environmental, and exergo-environmental performance of bottoming power cycles powered by the $\mathrm{CO}_{2}-\mathrm{C}_{7} \mathrm{H}_{8}$ binary mixture. Two plant architectures are studied for topping power loop exhaust heat utilization; namely, simple regenerative cycle (SRC) and partial heating cycle (PHC). Both architectures are presented in Figure 2. SRC is the simple architecture consists of one integrated heat exchanger (IHX) for waste heat utilization and a recuperator. This architecture is usually employed for waste heat recovery applications to conduct a comparative performance analysis with other complicated architectures. PHC is a marginally complex architecture including a stream with split after compression to enhance the heat utilization of high-temperature exhaust gases and to accomplish improved thermal matching in the recuperator. This architecture proved to be a highly ranked layout for waste heat recovery supercritical carbon dioxide power cycle applications $[13,37,38]$; therefore, this architecture is selected in this study for bottoming power cycles powered by $\mathrm{CO}_{2}-\mathrm{C}_{7} \mathrm{H}_{8}$ binary mixture.

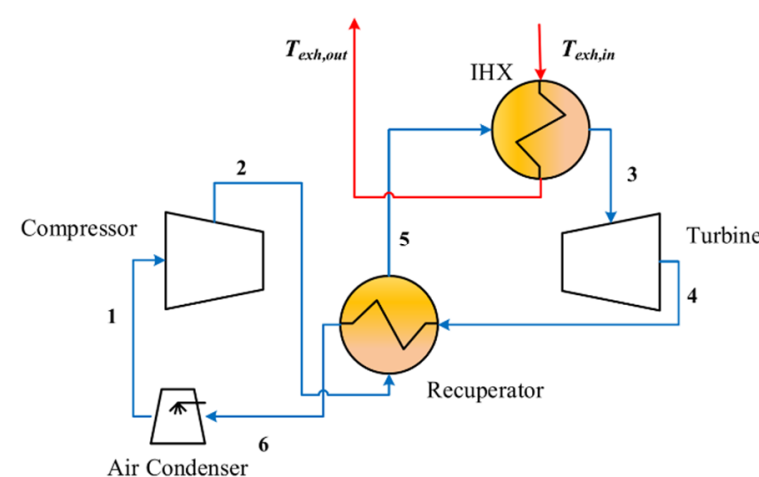

(a)

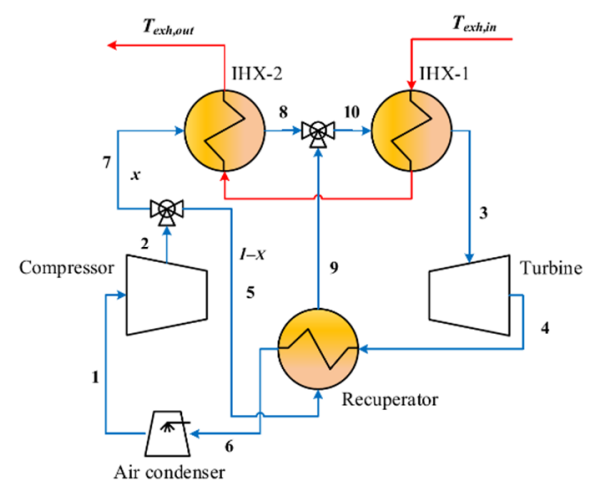

(b)

Figure 2. Bottoming cycle configurations: (a) Simple regenerative cycle (SRC); (b) Partial heating cycle (PHC). Adapted from [26].

Power cycle modeling and specifications are performed by using the ASPEN plus V9 process simulation tool [39]. The minimum temperature difference approach (MITA) is employed for the modeling of recuperator and IHX. According to this approach, the heat exchanger is divided into several internal zones, calculates temperature differences per zone by employing energy balance, and converges the temperatures at design MITA value. This approach is more reliable in comparison with traditional methods that assume the effectiveness of a heat exchanger and calculate the exit temperatures by considering the whole heat exchanger as a black box. In addition to this, the MITA approach provides the conditions of pinch point occurrence within the heat exchanger. Finally, the total UA of the heat exchanger is computed by the summation of the individual UA of each zone.

The range of P.R for sensitivity analysis is set from 2 to 4.4. The parameters studied are energy efficiency, exergy efficiency, mass flow rate of working fluid, heat recovery, net power produced, overall UA (sum of UA of all heat exchangers including IHX1, IHX2, recuperator and cooler), exergy destruction ratio, total components cost, plant-specific cost, levelized cost of electricity and 
$\mathrm{CO}_{2}$ emissions savings. Recommended P.R for all four cycles are decided based on maximum exergy efficiency and power output. In addition to this, exergy destruction and cost of individual components of power cycles are also investigated. Finally, exergy destruction (irreversibilities) in the components of power cycles operating with $0.9 \mathrm{CO}_{2}+0.1 \mathrm{C}_{7} \mathrm{H}_{8}$ binary mixture at the recommended P.R is also investigated.

\subsubsection{Energetic Analysis}

The thermodynamic model employed to examine the energetic performance of the bottoming power cycles is reported in this section. The energy balance computations are performed by using ASPEN and accompanied by computation of energetic efficiency $\left(\eta_{I}\right)$ and net power $\left(W_{\text {net }}\right)$ using Equations (1) and (2).

$$
\eta_{I}=\frac{\dot{W_{n e t}}}{\dot{Q_{i n}}}
$$

where

$$
\dot{W}_{\text {net }}=\dot{W}_{t}-\dot{W}_{c}
$$

and $\left(\dot{Q_{i n}}\right)$ is the net heat recovered from the exhaust gas stream of the topping power cycle.

\subsubsection{Exergetic Analysis}

To evaluate the exergetic performance of the bottoming power cycles, the exergy flow rate of every stream is computed and exergy destruction in power cycle components is determined by employing exergy balance [40]. Table 3 enclosed the exergy balance relations of each power cycle component.

Relations for exergetic efficiency $\left(\eta_{I I}\right)$, total exergy destroyed $\left(\dot{E}_{d}\right)$, net exergy in $\left(\dot{E}_{n e t, i n}\right)$ and exergy destruction ratio $\left(\dot{E}_{d,}\right.$ ratio $)$ are presented in Equations (3)-(6) as follows:

$$
\begin{gathered}
\eta_{I I}=1-\frac{\dot{E}_{d}}{\dot{E}_{n e t, \text { in }}} \\
\dot{E}_{d}=\dot{E}_{d, c}+\dot{E}_{d, t}+\dot{E}_{d, \text { rec }}+\dot{E}_{d, \text { cond }}+\dot{E}_{d, I H X 1}+\dot{E}_{d, I H X 2} \\
\dot{E}_{n e t, \text { in }}=\dot{E}_{x, \text { exhin }}-\dot{E}_{x, \text { exhout }} \\
\dot{E}_{d, \text { ratio }}=\frac{\dot{E}_{d}}{\dot{E}_{n e t, \text { in }}}
\end{gathered}
$$

\begin{tabular}{|c|c|c|}
\hline Component & Exergy Rate Balance Equations & Eq. No \\
\hline Compressor & $\dot{E}_{d, C}=\dot{W}_{C}+\dot{E}_{x, 1}-\dot{E}_{x, 2}$ & (7) \\
\hline Turbine & $\dot{E}_{d, T}=-\dot{W}_{T}+\dot{E}_{x, 3}-\dot{E}_{x, 4}$ & (8) \\
\hline Recuperator & $\dot{E}_{d, r e c}=\dot{E}_{x, 5}-\dot{E}_{x, 9}+\dot{E}_{x, 4}-\dot{E}_{x, 6}$ & (9) \\
\hline Condenser & $\dot{E}_{d, c o n d}=\dot{E}_{x, 6}-\dot{E}_{x, 1}+\dot{E}_{x, \text { Air in }}-\dot{E}_{x, \text { Air out }}$ & (10) \\
\hline IHX-1 & $\dot{E}_{d, I H X 1}=\dot{E}_{x, \text { exhin }}-\dot{E}_{x, \text { exhout }, i}+\dot{E}_{x, 10}-\dot{E}_{x, 3}$ & (11) \\
\hline IHX-2 & $\dot{E}_{d, I H X 2}=\dot{E}_{x, \text { exhin }, i}-\dot{E}_{x, \text { exhout }}+\dot{E}_{x, 7}-\dot{E}_{x, 8}$ & $(12)$ \\
\hline
\end{tabular}

Table 3. Exergy balance rate equations for components of the $\mathrm{sCO}_{2}$ bottoming power cycles. Adapted from [26]. 


\subsubsection{Air Condenser Modeling}

For the modeling of bottoming power cycles air condenser, a specific value of temperature difference is considered at the exit stream of condenser, i.e., $10^{\circ} \mathrm{C}$, and the minimum cycle temperature $\left(T_{\min }\right)$ or entry temperature of the compressor is computed using

$$
T_{\min }=T_{a m b}+10^{\circ} \mathrm{C}
$$

This model is advantageous to evade a highly low pinch point temperature difference (PPTD) in air condenser for the period of changing ambient temperatures $\left(T_{a m b}\right)$ [4].

\subsection{Economic Analysis}

To assess the economic significance of different architectures analyzed, two economic indicators are considered, namely plant-specific cost (PSC) and levelized cost of electricity (LCOE).

\subsubsection{Plant-Specific Cost}

The PSC is the basic indicator providing the unitary cost of the power production system in terms of USD $/ \mathrm{kWe}$ and can provide a qualitative concept to compare the cost of similar systems.

PSC is defined as

$$
P S C=\frac{C_{\text {total }}}{\dot{w}_{\text {net }}}
$$

In Equation (14), the numerator $\left(C_{\text {total }}\right)$ provides the capital investment cost of the power production system including total cost of cycle components, cost of auxiliaries, and installation costs (Equation (15)). The models employed for computing capital investment costs of individual cycle components are presented in Equations (16)-(20).

$$
\begin{gathered}
C_{\text {total }}=\left(C_{t}+C_{c}+C_{\text {Recup }}+C_{\text {Condenser }}+C_{I H X 1}+C_{I H X 2}\right) C_{\text {inst }} \\
C_{I H X}=17.5(U A[\mathrm{~W} / \mathrm{K}])^{0.8778} \\
C_{\text {Recup }}=5.2(U A[\mathrm{~W} / \mathrm{K}])^{0.8993} \\
C_{\text {Condenser }}=76.25(\mathrm{UA}[\mathrm{W} / \mathrm{K}])^{0.8919} \\
C_{t}=479.34 \dot{m}_{t}\left(\frac{1}{0.93-\eta_{t}}\right) \ln \left(P . R_{t}\right)(1+\exp (0.036 \mathrm{TIT}-54.4)) \\
C_{c}=71.1 \dot{m}_{c}\left(\frac{1}{0.92-\eta_{c}}\right)\left(P . R_{c}\right) \ln \left(P . R_{c}\right)
\end{gathered}
$$

The power plant installation cost is considered as a multiplier of investment cost equivalent to $30 \%$ [41]. This coefficient covers the cost of auxiliaries, i.e., motorized valves, refrigeration compressors to remove the drain and electrical connections, etc.

\subsubsection{Levelized Cost of Electricity}

Unlike PSC, the LCOE is rather a more comprehensive economic indicator that permits to evaluate the profitability level of investment value for a power production system. The LCOE assesses the average price for electricity production from a power plant. This indicator can be computed by using Equation (21) in terms of the proportion of the present Value of plant Expenses (PVE) including plant power production over its whole operating time. Operating time includes the net power produced, plant utilization factor $(u)$, and the lifetime $(N Y)$. These parameter values are enclosed in Table 4 [40].

$$
\mathrm{LCOE}=\frac{P V E}{8760 u N Y \dot{w}_{\text {net }}}
$$


Table 4. Assumptions for economic comparative analysis.

\begin{tabular}{cc}
\hline Parameters & Value \\
\hline Plant installation cost $\left(C_{\text {inst }}\right)$ & 1.3 \\
Operation and Maintenance cost $(O M)(\mathrm{USD} / \mathrm{kWe})$ & 30 \\
Operation and Maintenance Escalation rate $(\mathrm{er})(\%)$ & 3 \\
Plant lifetime $(N Y)($ years $)$ & 20 \\
Plant utilization factor $(u)(\%)$ & 85 \\
Discount rate $(r)(\%)$ & 5 \\
\hline
\end{tabular}

The formulation for PVE is stated in Equation (22), which includes the cash flow calculations of the plant expenditures by using Equation (23). In this research, operations and maintenance cost of one kWe power installed is taken into consideration by using parameter $O M$ whereas the escalation rate for this cost is taken into consideration by using coefficient $e r$. These pieces of information are enclosed in Table 4 including the discount rate $(r)$.

$$
\begin{gathered}
P V E=C_{t o t} \sum_{k=1}^{N Y} \frac{C F_{X p, k}}{(1+r)^{k}} \\
C F_{x, p} \dot{k}=w_{\text {net }}\left(O M(1+e r)^{k}\right)
\end{gathered}
$$

\subsection{Exergo-Environmental Analysis}

In the current century, it is important to perform a detailed environmental analysis of the power production systems under investigation to assure that they have a least or no harmful effects on the atmosphere. This portion of the paper combines exergetic and environmental analysis to display a modern type of research called exergo-environmental analysis. It is established based on exergetic analysis and considers exergy efficiency and exergy destruction to measure its impact on the environment. Exergo-environmental analysis comprises six indicators, namely, exergo-environmental impact factor, exergo-environmental impact coefficient, exergo-environmental impact index, exergo-environmental impact improvement, exergetic stability factor, and exergetic sustainability index [42,43].

\subsubsection{Exergo-Environmental Impact Factor}

The exergo-environmental impact factor $\left(f_{e i}\right)$ identifies the positive impact of the system under investigation on the atmosphere. The reason of considering this indicator is that it assists to minimize the environmental impact of the power production system by reducing the irreversibilities in the system.

The ideal value of $f_{e i}$ is zero, which means that the system possesses no irreversibility. It is the ratio of total exergy rate destroyed $\left(\dot{E} x_{\text {dest,tot }}\right)$ by the system and total exergy rate provided to the system $\left(\sum \dot{E} x_{i n}\right)$ as defined in Equation (24).

$$
f_{e i}=\frac{\dot{E} x_{\text {dest }, \text { tot }}}{\sum \dot{E} x_{i n}}
$$

\subsubsection{Exergo-Environmental Impact Coefficient}

The exergo-environmental impact coefficient $\left(C_{e i}\right)$ is associated with exergy efficiency $\left(\eta_{e x}\right)$ of the system. The ideal value of this indicator must be one, demonstrating that the system under consideration is working in ideal circumstances with zero exergy destruction. This indicator is formulated as (Equation (25)).

$$
C_{e i}=\frac{1}{\eta_{e x} / 100}
$$




\subsubsection{Exergo-Environmental Impact Index}

The exergo-environmental impact index $\left(\theta_{e i}\right)$ is a significant indicator to study, since it shows whether the system subjected to investigation harms the environment by its unproductive waste exergy and exergy destroyed or not. Its desired value must be as minimum as possible. It is the product of $\left(f_{e i}\right)$ and $\left(C_{e i}\right)$ as defined below in Equation (26).

$$
\theta_{e i}=f_{e i} \times C_{e i}
$$

\subsubsection{Exergo-Environmental Impact Improvement}

The exergo-environmental impact improvement $\left(\theta_{\text {eii }}\right)$ indicator supports to find the environmental suitability of the system under study. To enhance the environmental suitability level of the analyzed system, its $\left(\theta_{e i}\right)$ value should be reduced. A large value of $\left(\theta_{e i i}\right)$ means, the system is highly beneficial for the environment and is formulated as (Equation (27)).

$$
\theta_{e i i}=\frac{1}{\theta_{\mathrm{e} i}}
$$

\subsubsection{Exergetic Stability Factor}

The exergetic stability factor $\left(f_{e s}\right)$ depends on the total exergy out $\left(\dot{E} x_{t o t, o u t}\right)$, total exergy destroyed $\left(\dot{E} x_{d e s t, t o t}\right)$ and exergy wasted by unproductive fuel $\left(\dot{E} x_{u u}\right)$ as shown in Equation (28). The required value of this indicator should be nearest to one.

$$
f_{e s}=\frac{\dot{E} x_{t o t, o u t}}{\dot{E} x_{t o t, o u t}+\dot{E} x_{d e s t, t o t}+\dot{E} x_{u u}}
$$

\subsubsection{Exergetic Sustainability Index}

The exergetic sustainability index $\left(\theta_{e s t}\right)$ is the product of $\left(f_{e s}\right)$ and $\left(\theta_{e i i}\right)$ of the power production system as enclosed in Equation (29). The required value of this indicator needs to be as higher as possible.

$$
\theta_{e s t}=f_{e s} \times \theta_{e i i}
$$

\section{5. $\mathrm{CO}_{2}$ Emissions Savings}

Bottoming supercritical carbon dioxide power cycles do not produce any harmful emissions because they are closed-loop power production systems. As a consequence of waste heat utilization, they can benefit the earth ecosystem in terms of minimizing greenhouse emissions compared to fossil fuel power plants of the same power production. For the assessment of environmental impacts, the bottoming supercritical carbon dioxide power cycles examined in this study are compared with the fossil fuel plant of similar power output. The savings in $\mathrm{CO}_{2}$ emissions for a unit hour is evaluated by employing the following relation.

$$
M_{\mathrm{CO}_{2}}=\alpha_{\mathrm{CO}_{2}} \times \dot{W}_{\text {net }}
$$

In Equation (30), $\alpha_{\mathrm{CO}_{2}}$ is the measure of $\mathrm{CO}_{2}$ emitted from fossil fuel power-generating systems for $1 \mathrm{kWh}$ production. This parameter is computed by using Equation (31). The average operating heat rate $\left(H R_{\text {Natural gas }}\right)$ and emissions factor $\left(E F_{\text {Natural gas }}\right)$ of natural gas are extracted from the updated data accessible on the U.S. Energy Information Administration website [44]. From the updated data, the $H R_{\text {Natural gas }}$ and $E F_{\text {Natural gas }}$ values are $7821 \mathrm{Btu} / \mathrm{kWh}$ and $53.07 \mathrm{kgCO}_{2} /$ millions-Btu, respectively.

$$
\alpha_{\mathrm{CO}_{2}}=H R_{\text {Natural gas }} \times E F_{\text {Natural gas }}
$$




\section{Results and Discussion}

This section presents the 4E (Energy, Exergy, Economic and Environment) analysis of bottoming power cycles (SRC and $\mathrm{PHC}$ ) operating with pure $\mathrm{CO}_{2}$ and $0.9 \mathrm{CO}_{2}+0.1 \mathrm{C}_{7} \mathrm{H}_{8}$ binary mixture as working fluids. It is essential to study the effect of key performance indicators and their influence on power production. For the sake of fair comparison between four types of power cycles and taking into consideration that exhaust gases of GE LM2500 [36] topping gas turbine is used as a heat source for power generation, the input operating (base) conditions are shown in Table 5.

Table 5. Base conditions for the parametric study $[25,45]$.

\begin{tabular}{ccc}
\hline Input Parameters in the Cycles & Value & Unit \\
\hline Dead state temperature $\left(T_{0}\right)$ & 313 & $\mathrm{~K}$ \\
Minimum temperature difference in IHX1 & 10 & $\mathrm{~K}$ \\
Minimum temperature difference in IHX2 & 10 & $\mathrm{~K}$ \\
Minimum temperature difference in Recuperator & 30 & $\mathrm{~K}$ \\
Isentropic efficiency of turbine & 85 & $\%$ \\
Isentropic efficiency of compressor & 80 & $\%$ \\
Turbine inlet temperature $(T I T)$ & 673 & $\mathrm{~K}$ \\
Compressor inlet temperature $\left(T_{\min }\right)$ & 323 & $\mathrm{~K}$ \\
Compressor inlet pressure $\left(P_{\text {min }}\right)$ & 9.14 & $\mathrm{MPa}$ \\
\hline
\end{tabular}

Figures 3-10 demonstrate the results of the comparative study of the four bottoming power cycles. Three types of comparative studies are performed, i.e., (1) comparative study between pure $\mathrm{CO}_{2}$ bottoming power cycles $\left(\mathrm{CO}_{2} \mathrm{SRC}\right.$ vs. $\left.\mathrm{CO}_{2} \mathrm{PHC}\right)$; (2) comparative study between SRCs operating with pure $\mathrm{CO}_{2}$ and $\mathrm{CO}_{2}$-based binary mixture $\left(\mathrm{CO}_{2} \mathrm{SRC}\right.$ vs. $\left.0.9 \mathrm{CO}_{2} / 0.1 \mathrm{C}_{7} \mathrm{H}_{8} \mathrm{SRC}\right)$; (3) comparative study between PHCs operating with pure $\mathrm{CO}_{2}$ and $\mathrm{CO}_{2}$-based binary mixture $\left(\mathrm{CO}_{2} \mathrm{PHC}\right.$ vs. $0.9 \mathrm{CO}_{2} / 0.1 \mathrm{C}_{7} \mathrm{H}_{8}$ $\mathrm{PHC}$ ); cycle minimum pressure (Pmin) is the saturation pressure (bubble pressure) at the cycle minimum temperature $\left(T_{\min }\right)$ in case of power cycles operating with $0.9 \mathrm{CO}_{2} / 0.1 \mathrm{C}_{7} \mathrm{H}_{8}$ binary mixture. Dead state temperature $(313 \mathrm{~K})$ is the average ambient temperature taken from the data of BWh climatic zone regions.

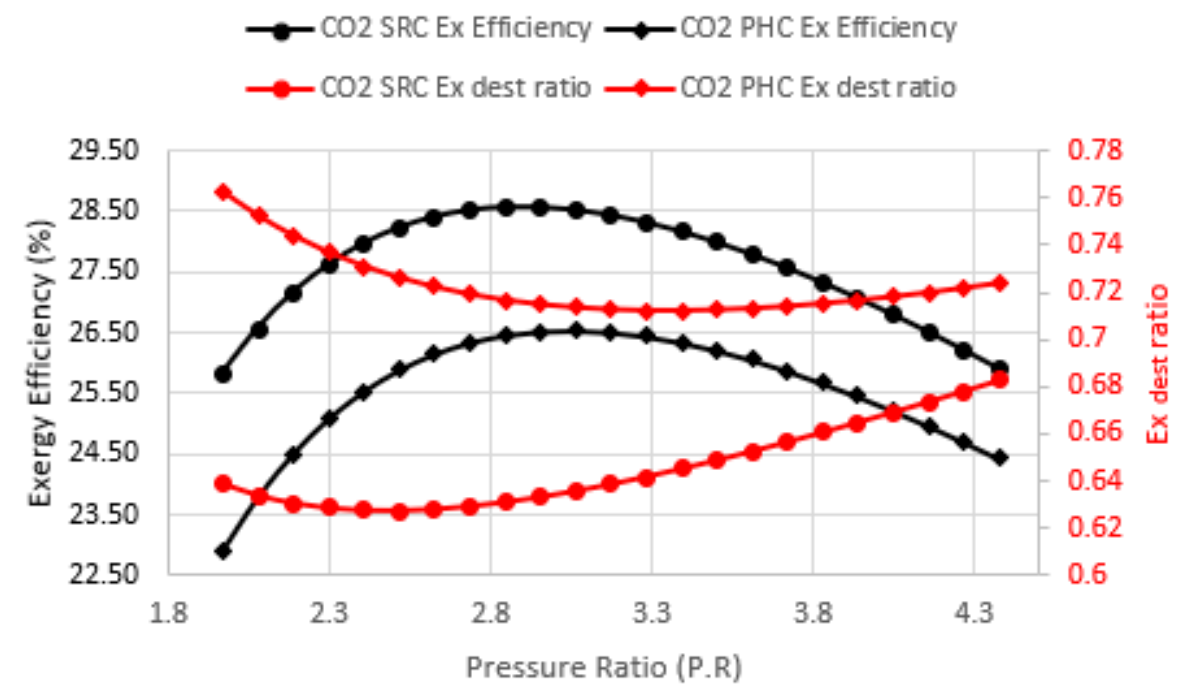

Figure 3. Exergetic efficiency and exergy destruction ratio of $\mathrm{CO}_{2} \mathrm{SRC}$ and $\mathrm{PHC}$ with respect to pressure ratio. 


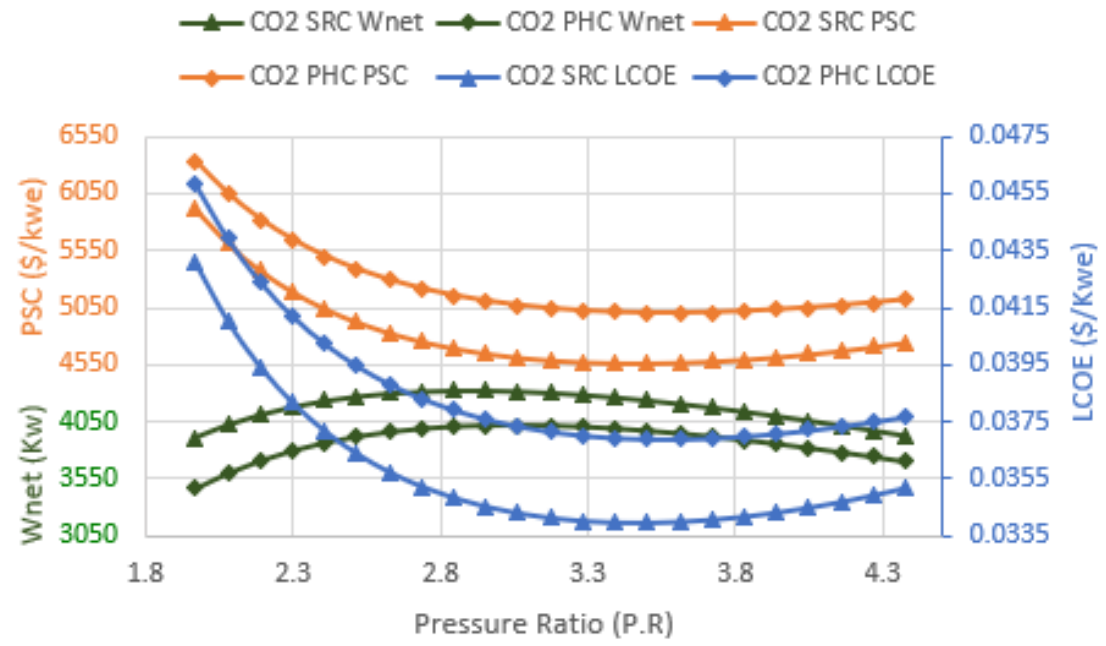

Figure 4. Power output, plant-specific cost and levelized cost of electricity for $\mathrm{CO}_{2} \mathrm{SRC}$ and $\mathrm{PHC}$ with respect to pressure ratio.

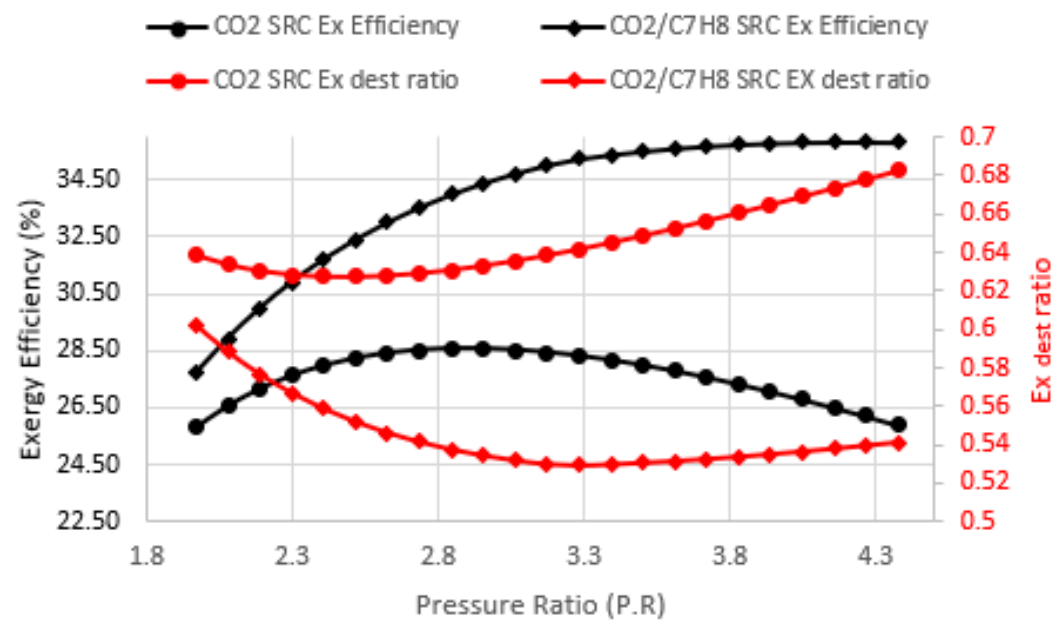

Figure 5. Exergetic efficiency and exergy destruction ratio of $\mathrm{CO}_{2} \mathrm{SRC}$ and $0.9 \mathrm{CO}_{2} / 0.1 \mathrm{C}_{7} \mathrm{H}_{8} \mathrm{SRC}$ with respect to pressure ratio.
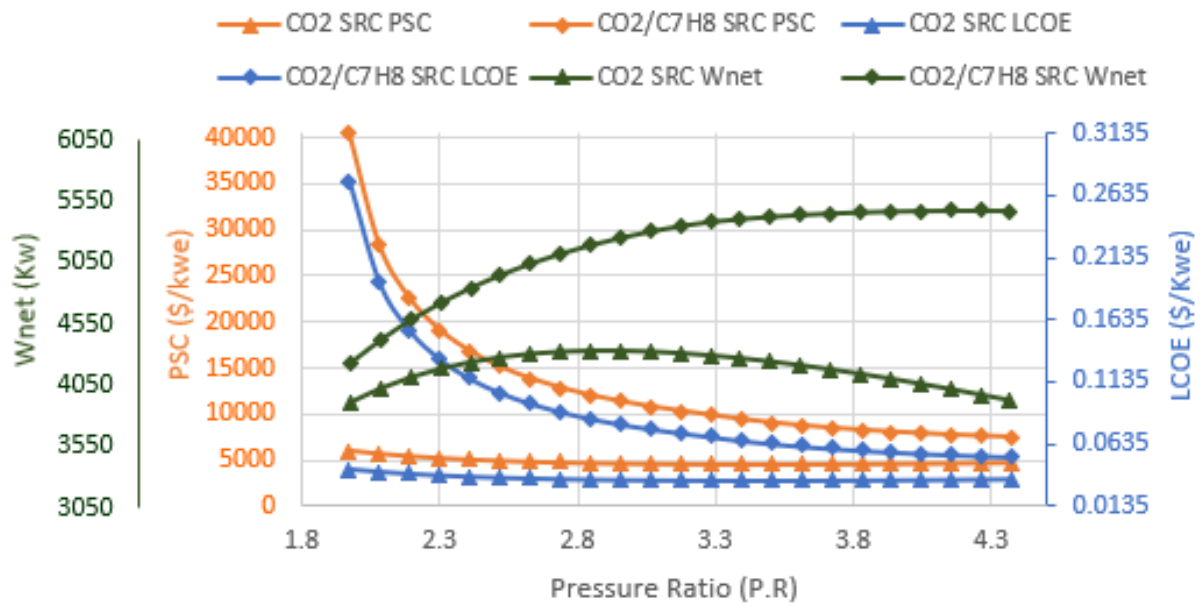

Figure 6. Power output, plant-specific cost, and levelized cost of electricity for $\mathrm{CO}_{2} \mathrm{SRC}$ and $0.9 \mathrm{CO}_{2} / 0.1 \mathrm{C}_{7} \mathrm{H}_{8} \mathrm{SRC}$ with respect to pressure ratio. 


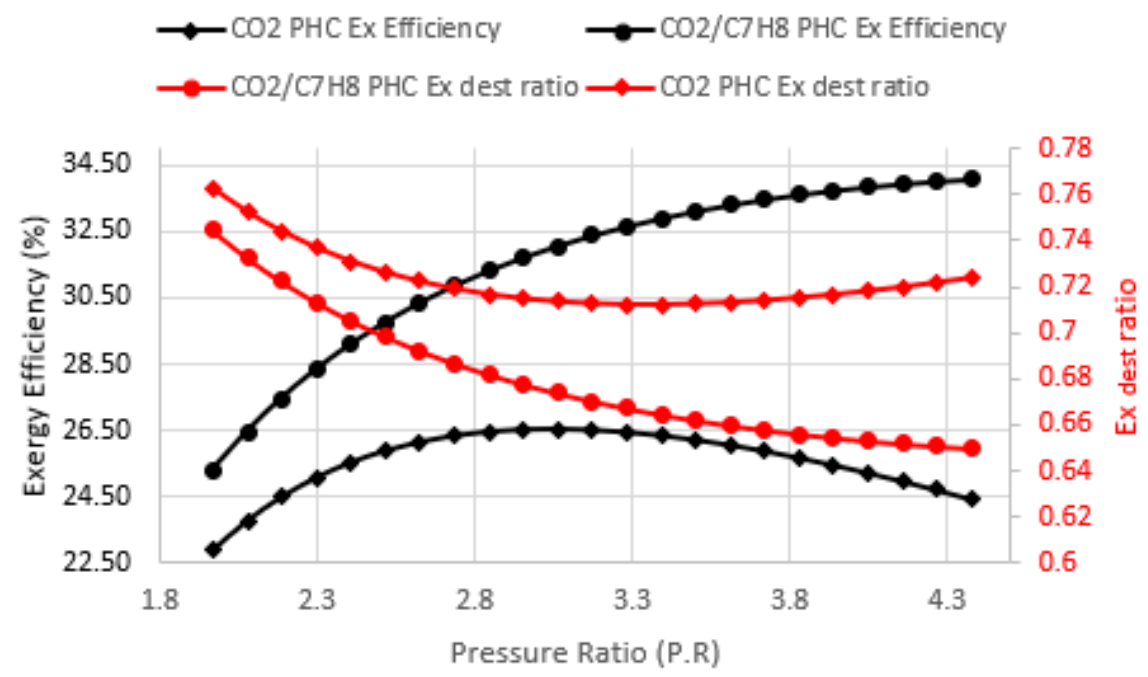

Figure 7. Exergetic efficiency and exergy destruction ratio of $\mathrm{CO}_{2} \mathrm{PHC}$ and $0.9 \mathrm{CO}_{2} / 0.1 \mathrm{C}_{7} \mathrm{H}_{8} \mathrm{PHC}$ concerning pressure ratio.

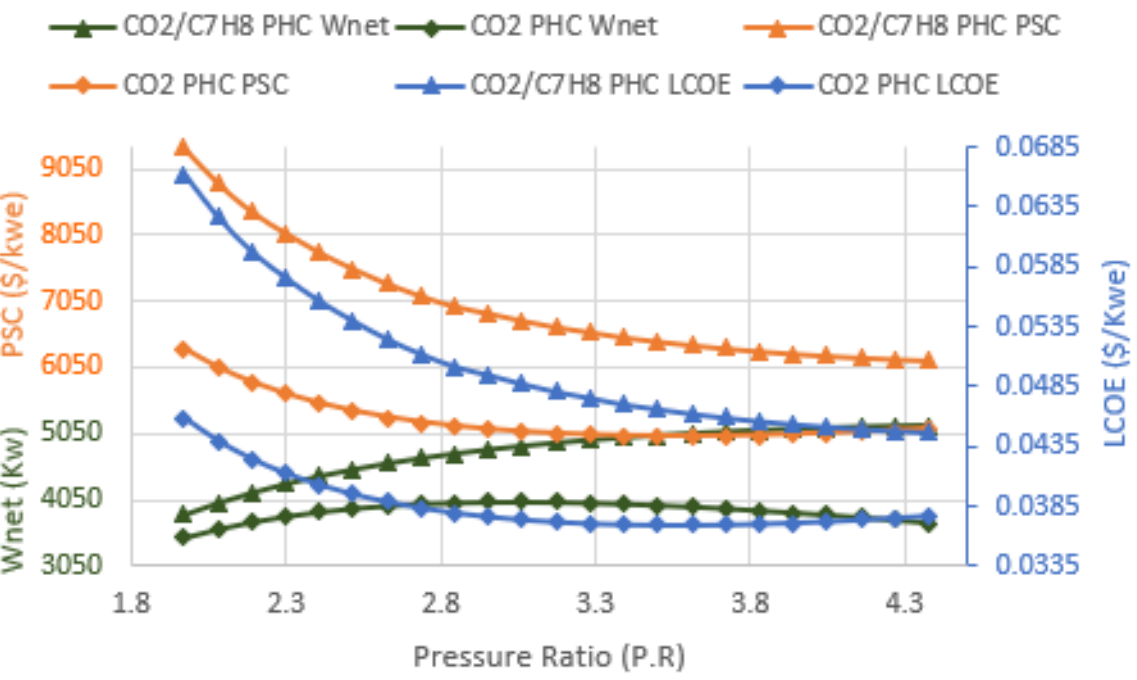

Figure 8. Power output, plant-specific cost and levelized cost of electricity for $\mathrm{CO}_{2} \mathrm{PHC}$ and $0.9 \mathrm{CO}_{2} / 0.1 \mathrm{C}_{7} \mathrm{H}_{8} \mathrm{PHC}$ with respect to pressure ratio.

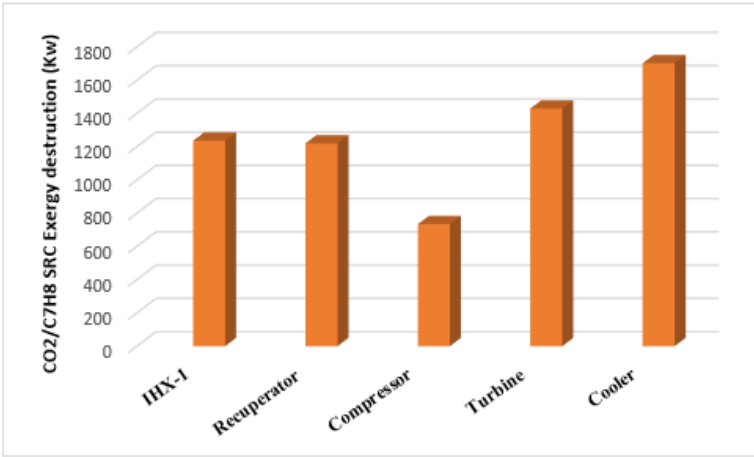

(a)

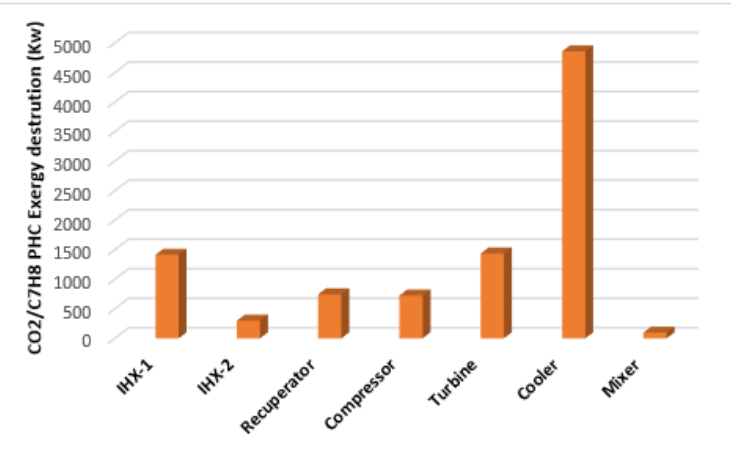

(b)

Figure 9. (a) Exergy destruction in components of SRC and (b) $\mathrm{PHC}$ operating with $0.9 \mathrm{CO}_{2} / 0.1 \mathrm{C}_{7} \mathrm{H}_{8}$ binary mixture. 


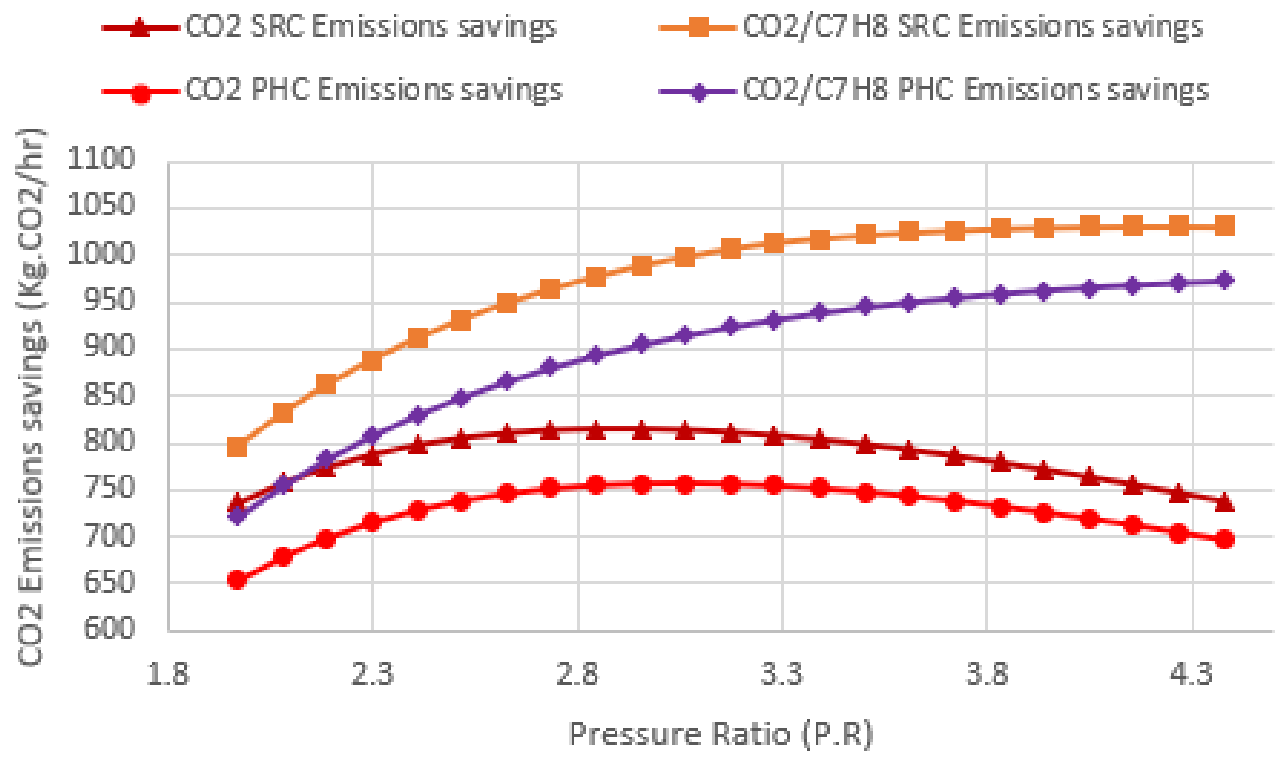

Figure 10. $\mathrm{CO}_{2}$ emissions savings for power cycles operating with $\mathrm{CO}_{2}$ and $0.9 \mathrm{CO}_{2} / 0.1 \mathrm{C}_{7} \mathrm{H}_{8}$ binary mixture with respect to pressure ratio.

\subsection{Comparison between $\mathrm{CO}_{2} \mathrm{SRC}$ and $\mathrm{CO}_{2} \mathrm{PHC}$}

Figure 3 illustrates the exergy efficiency and exergy destruction ratio of both SRC and PHC operating with pure $\mathrm{CO}_{2}$ as the working fluid. In both configurations, the exergy efficiency and exergy destruction ratios show an inverse relationship with each other. It can be observed that maximum exergetic performance occurs at the pressure ratio of 2.8 for $\mathrm{CO}_{2} \mathrm{SRC}$. For $\mathrm{CO}_{2} \mathrm{PHC}$, maximum exergetic performance occurs at the pressure ratio of 3.1. Therefore, these two pressure ratios are recommended to achieve maximum cycles' performance. The exergetic performance of SRC is higher than PHC mainly due to the larger exergy destruction ratio in PHC components.

Figure 4 shows the performance curves of power output, plant-specific cost, and levelized cost of electricity for both SRC and PHC operating with pure $\mathrm{CO}_{2}$ with respect to pressure ratio. Both the plant-specific cost and the levelized cost of electricity show inverse relation with the power output of power cycles. It can be observed that maximum power output occurs at the pressure ratio of 2.8 for $\mathrm{CO}_{2}$ SRC. For $\mathrm{CO}_{2} \mathrm{PHC}$, maximum power output occurs at the pressure ratio of 3.1 as in the case of exergy efficiency. The power output of SRC is higher than PHC with less plant-specific cost and the levelized cost of electricity at all pressure ratios.

\subsection{Comparison between $\mathrm{CO}_{2} \mathrm{SRC}$ and $0.9 \mathrm{CO}_{2} / 0.1 \mathrm{C}_{7} \mathrm{H}_{8} \mathrm{SRC}$}

Figure 5 presents the exergy efficiency and exergy destruction ratio of both SRCs operating with pure $\mathrm{CO}_{2}$ and $0.9 \mathrm{CO}_{2} / 0.1 \mathrm{C}_{7} \mathrm{H}_{8}$ as working fluids. In both power cycles, exergy efficiency and exergy destruction ratio show an inverse relationship with each other. It can be observed that maximum exergetic performance occurs at the pressure ratio of 4.1 for $0.9 \mathrm{CO}_{2} / 0.1 \mathrm{C}_{7} \mathrm{H}_{8} \mathrm{SRC}$. Therefore, this pressure ratio is recommended to achieve maximum cycle performance. The exergetic performance of $0.9 \mathrm{CO}_{2} / 0.1 \mathrm{C}_{7} \mathrm{H}_{8} \mathrm{SRC}$ is higher than pure $\mathrm{CO}_{2} \mathrm{SRC}$ mainly due to the larger exergy destruction ratio in $\mathrm{CO}_{2} \mathrm{SRC}$ components.

Figure 6 shows the behavior of power output, plant-specific cost, and levelized cost of electricity for both SRCs operating with pure $\mathrm{CO}_{2}$ and $0.9 \mathrm{CO}_{2} / 0.1 \mathrm{C}_{7} \mathrm{H}_{8}$ as working fluids for varying pressure ratio. Both the plant-specific cost and the levelized cost of electricity show a decreasing trend with the increase in pressure ratio in the case of $0.9 \mathrm{CO}_{2} / 0.1 \mathrm{C}_{7} \mathrm{H}_{8} \mathrm{SRC}$. It can be observed that maximum power output occurs at the pressure ratio of 4.1 for $0.9 \mathrm{CO}_{2} / 0.1 \mathrm{C}_{7} \mathrm{H}_{8} \mathrm{SRC}$ as in the case of exergy efficiency. It is evident that the power output of $0.9 \mathrm{CO}_{2} / 0.1 \mathrm{C}_{7} \mathrm{H}_{8} \mathrm{SRC}$ is higher than pure $\mathrm{CO}_{2} \mathrm{SRC}$ at 
the expense of high plant-specific cost and the levelized cost of electricity at all pressure ratios. In the case of $0.9 \mathrm{CO}_{2} / 0.1 \mathrm{C}_{7} \mathrm{H}_{8} \mathrm{SRC}$, a very high values of plant-specific cost and levelized cost of electricity is also visible at lower pressure ratios, which is the sign of very low minimum temperature (MITA) in the cooler, resulting in very high UA values and economic indicators. Therefore, low values of pressure ratios are not suitable for the operation of bottoming power cycles operating with a $\mathrm{CO}_{2}$-based binary mixture.

\subsection{Comparison between $\mathrm{CO}_{2} \mathrm{PHC}$ and $0.9 \mathrm{CO}_{2} / 0.1 \mathrm{C}_{7} \mathrm{H}_{8} \mathrm{PHC}$}

Figure 7 presents the exergy efficiency and exergy destruction ratio of both $\mathrm{PHCs}$ operating with pure $\mathrm{CO}_{2}$ and $0.9 \mathrm{CO}_{2} / 0.1 \mathrm{C}_{7} \mathrm{H}_{8}$ as working fluids. In both power cycles, exergy efficiency and exergy destruction ratio show an inverse relationship with each other. It can be observed that maximum exergetic performance occurs at the pressure ratio of 4.4 for $0.9 \mathrm{CO}_{2} / 0.1 \mathrm{C}_{7} \mathrm{H}_{8} \mathrm{PHC}$. Therefore, this pressure ratio is recommended to achieve maximum cycle performance. The exergetic performance of $0.9 \mathrm{CO}_{2} / 0.1 \mathrm{C}_{7} \mathrm{H}_{8} \mathrm{PHC}$ is better than pure $\mathrm{CO}_{2} \mathrm{PHC}$ mainly due to the larger exergy destruction ratio in $\mathrm{CO}_{2} \mathrm{PHC}$ components.

Figure 8 shows the behavior of power output, plant-specific cost, and levelized cost of electricity for both PHCs operating with pure $\mathrm{CO}_{2}$ and $0.9 \mathrm{CO}_{2} / 0.1 \mathrm{C}_{7} \mathrm{H}_{8}$ as working fluids for varying pressure ratio. Both plant-specific cost and levelized cost of electricity show a decreasing trend with the increase in pressure ratio in the case of $0.9 \mathrm{CO}_{2} / 0.1 \mathrm{C}_{7} \mathrm{H}_{8} \mathrm{PHC}$. It can be observed that maximum power output occurs at the pressure ratio of 4.4 for $0.9 \mathrm{CO}_{2} / 0.1 \mathrm{C}_{7} \mathrm{H}_{8} \mathrm{PHC}$ as in the case of exergy efficiency. It is evident that the power output of $0.9 \mathrm{CO}_{2} / 0.1 \mathrm{C}_{7} \mathrm{H}_{8} \mathrm{PHC}$ is higher than pure $\mathrm{CO}_{2} \mathrm{PHC}$ at the expense of high plant-specific cost and the levelized cost of electricity at all pressure ratios.

Component wise exergy destruction in power cycles (SRC and PHC) operating with $0.9 \mathrm{CO}_{2} / 0.1 \mathrm{C}_{7} \mathrm{H}_{8}$ binary mixture at recommended pressure ratios is illustrated in Figure 9 . In both power cycles, maximum exergy is destroyed in cooler. The reason behind this is the large temperature differences between hot and cold stream in the cooler at higher pressure ratios. The second highest exergy destruction component is the turbine for both power cycles due to large turbine work at higher pressure ratios. A greater number of components and very high exergy destruction in the cooler results in a lower exergy efficiency of the PHC compared to SRC, as discussed earlier.

The trend of $\mathrm{CO}_{2}$ emissions savings at varying pressure ratio for both working fluids is shown in Figure 10. SRC with $\mathrm{CO}_{2} / \mathrm{C}_{7} \mathrm{H}_{8}$ shows maximum savings owing to larger power output in a bottoming cycle. Whereas, both cycle configurations with pure $\mathrm{CO}_{2}$ comparatively show lower $\mathrm{CO}_{2}$ emissions savings especially at higher pressure ratios.

The summary of thermodynamic, economic and environmental results of the considered power cycles with their corresponding recommended pressure ratios are shown in Tables 6 and 7. Power cycles operating with the $\mathrm{CO}_{2}-\mathrm{C}_{7} \mathrm{H}_{8}$ mixture show greater power output, exergy efficiency, smaller mass flow rates yet at the expense of larger levelized cost of electricity compared to cycles with pure $\mathrm{CO}_{2}$ working fluid. In terms of environmental impact and sustainability indices, cycles operating with $\mathrm{CO}_{2}-\mathrm{C}_{7} \mathrm{H}_{8}$ mixture show significant improvement, as is evident from Table 7.

An exhaustive comparison with other thermodynamic power cycles like steam Rankine cycles and organic Rankine cycles is also essential yet difficult because of different design parameters assumed by different authors and different type of sensitivity analysis. Meanwhile, there are some recent studies that deal with a comparative analysis of $\mathrm{sCO}_{2}$ and other traditional power cycles. Manente et al. [45] presented a thorough thermo-economic comparison among different $\mathrm{sCO}_{2}$ cycle layouts for waste heat recovery. There is another current work by Ayub et al. [25] which focuses on thermodynamic comparison between $\mathrm{sCO}_{2}$ cycles and organic Rankine cycles for high temperature waste heat recovery. The work suggests $\mathrm{CO}_{2}-\mathrm{R} 134 \mathrm{a}$ binary mixture as working fluid in simple recuperative cycle layout owing to higher thermodynamic performance, lower recuperator and turbine sizes and lower maximum operating pressures compared to $\mathrm{SCO}_{2}$ cycle and organic Rankine cycle with R134a working fluid. 
Table 6. Thermodynamic performance indicators at recommended pressure ratios for all four bottoming power cycles.

\begin{tabular}{|c|c|c|c|c|c|c|c|c|}
\hline Power Cycles & $\begin{array}{l}\text { Recommended } \\
\text { Pressure Ratio }\end{array}$ & $\begin{array}{c}\text { Energy } \\
\text { Efficiency } \\
(\%)\end{array}$ & $\begin{array}{c}\text { Exergy } \\
\text { Efficiency } \\
(\%)\end{array}$ & $\begin{array}{c}\text { Power } \\
\text { Output } \\
(\mathbf{k W})\end{array}$ & $\begin{array}{c}\text { Heat } \\
\text { Recovery } \\
(\mathbf{k W})\end{array}$ & $\begin{array}{c}\text { Exergy } \\
\text { Destruction } \\
\text { Ratio }\end{array}$ & $\begin{array}{c}\text { Mass Flow } \\
\text { Rate } \\
(\mathrm{kg} / \mathrm{sec})\end{array}$ & $\begin{array}{c}\text { Mass Split } \\
\text { (towards } \\
\text { IHX-2) }\end{array}$ \\
\hline $\mathrm{CO}_{2} \mathrm{SRC}$ & 2.8 & 19.0 & 28.6 & 4328.2 & $22,742.7$ & 0.631 & 101.3 & No split \\
\hline $0.9 \mathrm{CO}_{2} / 0.1 \mathrm{C}_{7} \mathrm{H}_{8} \mathrm{SRC}$ & 4.1 & 23.7 & 35.8 & 5473.3 & $23,053.3$ & 0.538 & 80.9 & No split \\
\hline $\mathrm{CO}_{2} \mathrm{PHC}$ & 3.1 & 13.5 & 26.5 & 4020.8 & $29,835.9$ & 0.713 & 92.1 & 0.73 \\
\hline $0.9 \mathrm{CO}_{2} / 0.1 \mathrm{C}_{7} \mathrm{H}_{8} \mathrm{PHC}$ & 4.4 & 15.6 & 34.1 & 5163.8 & $33,165.0$ & 0.649 & 75.6 & 0.68 \\
\hline
\end{tabular}

Table 7. Economic and Environmental performance indicators at recommended pressure ratios for all four bottoming power cycles.

\begin{tabular}{|c|c|c|c|c|c|c|c|c|}
\hline Power Cycles & $\begin{array}{l}\text { Recommended } \\
\text { Pressure Ratio }\end{array}$ & $\begin{array}{c}\text { Overall } \\
\text { UA } \\
(\mathbf{k W} / \mathbf{K})\end{array}$ & $\begin{array}{c}\text { Total } \\
\text { Component } \\
\text { Cost } \\
\text { (MUSD) }\end{array}$ & $\begin{array}{c}\text { Plant-Specific } \\
\text { Cost } \\
\text { (USD/kWe) }\end{array}$ & $\begin{array}{l}\text { Levelized } \\
\text { Cost of } \\
\text { Electricity } \\
\text { (USD/kWe) }\end{array}$ & $\begin{array}{c}\mathrm{CO}_{2} \\
\text { Emissions } \\
\text { Savings } \\
\left.\text { (kg. } \mathrm{CO}_{2} / \mathrm{hr}\right)\end{array}$ & $\begin{array}{c}\text { Exergo } \\
\text { Environmental } \\
\text { Impact } \\
\text { Improvement } \\
\left(\theta_{i i}\right) \\
\end{array}$ & $\begin{array}{c}\text { Exergetic } \\
\text { Sustainability } \\
\text { Index }\left(\theta_{e s t}\right)\end{array}$ \\
\hline $\mathrm{CO}_{2} \mathrm{SRC}$ & 2.8 & 1524.1 & 20.32 & 4695 & 0.035 & 814.9 & 0.453 & 0.129 \\
\hline $0.9 \mathrm{CO}_{2} / 0.1 \mathrm{C}_{7} \mathrm{H}_{8} \mathrm{SRC}$ & 4.1 & 2812.4 & 42.15 & 7701 & 0.055 & 1030.4 & 0.667 & 0.239 \\
\hline $\mathrm{CO}_{2} \mathrm{PHC}$ & 3.1 & 1497.8 & 20.38 & 5069 & 0.037 & 756.9 & 0.372 & 0.0987 \\
\hline $0.9 \mathrm{CO}_{2} / 0.1 \mathrm{C}_{7} \mathrm{H}_{8} \mathrm{PHC}$ & 4.4 & 2228.3 & 31.82 & 6161 & 0.045 & 972.2 & 0.525 & 0.178 \\
\hline
\end{tabular}

\section{Conclusions}

This study analyzes the performance of bottoming power cycles with pure $\mathrm{CO}_{2}$ and $\mathrm{CO}_{2}-\mathrm{C}_{7} \mathrm{H}_{8}$ mixture as working fluid taking into account the thermodynamic, economic and environmental indices. Thermodynamic analysis at varying cycle pressure ratios show that a cycle with $\mathrm{CO}_{2}-\mathrm{C}_{7} \mathrm{H}_{8}$ mixture shows maximum power output and exergy efficiency at rather higher cycle pressure ratio compared to pure $\mathrm{CO}_{2}$ power cycles. However, the required mass flowrates of $\mathrm{CO}_{2}-\mathrm{C}_{7} \mathrm{H}_{8}$ mixture are smaller than pure $\mathrm{CO}_{2}$.

Due to larger heat recovery and exergy efficiency, cycles with a $\mathrm{CO}_{2}-\mathrm{C}_{7} \mathrm{H}_{8}$ mixture saves larger $\mathrm{CO}_{2}$ emissions, also showing greater exergy-environmental impact improvement, and plant sustainability index. On the contrary, economic analysis shows higher plant-specific cost and levelized cost of electricity mainly due to higher operating pressure ratios and larger recuperator and cooler sizes.

In particular, $\mathrm{PHC}$ with $\mathrm{CO}_{2}-\mathrm{C}_{7} \mathrm{H}_{8}$ mixture shows $28.68 \%$ increment in exergy efficiency with LCOE $21.62 \%$ higher than pure $\mathrm{CO}_{2} \mathrm{PHC}$. In additions, SRC with $\mathrm{CO}_{2}-\mathrm{C}_{7} \mathrm{H}_{8}$ mixture shows $25.17 \%$ increment in exergy efficiency with LCOE $57.14 \%$ higher than pure $\mathrm{CO}_{2} \mathrm{SRC}$.

The key outcome of this work is the better exergy efficiency and environmental sustainability benefit by using $\mathrm{CO}_{2}-\mathrm{C}_{7} \mathrm{H}_{8}$ binary mixture in bottoming $\mathrm{sCO}_{2}$ cycles. However, the rise in cycle-specific and levelized costs of electricity in the case of $\mathrm{CO}_{2}-\mathrm{C}_{7} \mathrm{H}_{8}$ working fluid is demanding. Therefore, more comprehensive research studying some new $\mathrm{CO}_{2}$ mixtures in bottoming $\mathrm{sCO}_{2}$ cycles is required. The study on new $\mathrm{CO}_{2}$ mixtures requires experimental VLE properties to optimize the parameters of equation of state (EOS) and information about thermal stability and transport properties of the pure fluids and mixtures.

Author Contributions: Conceptualization, M.H.; methodology, M.H., A.A.; software, M.H.; investigation, M.H., N.A.S., A.A.; writing—original draft preparation, M.H., N.A.S., A.A., R.T.; revision and final editing, A.T.B., M.H., F.S., M.I. All authors have read and agreed to the published version of the manuscript.

Funding: This research received no external funding.

Conflicts of Interest: The authors declare no conflict of interest. 


\section{Abbreviations}

The following abbreviations, symbols and subscripts are used in this manuscript:

\begin{tabular}{|c|c|}
\hline$C_{\text {inst }}$ & Installation cost \\
\hline $\mathrm{EF}$ & Emission factor $\left(\mathrm{kgCO}_{2} /\right.$ millions-Btu $)$ \\
\hline EOS & Equation of state \\
\hline GE & General electric \\
\hline GWP & Global warming potential \\
\hline HR & Heat rate $(\mathrm{Btu} / \mathrm{kWh})$ \\
\hline HSE & Health safety and environment \\
\hline IHX & Integrated heat exchanger \\
\hline LCOE & Levelized cost of electricity (USD/kWe) \\
\hline MITA & Minimum temperature approach $(\mathrm{K})$ \\
\hline MUSD & Mega Us dollars \\
\hline ODP & Ozone depletion potential \\
\hline ORC & Organic Rankine cycle \\
\hline PSC & Plant-specific cost (USD/kWe) \\
\hline PHC & Partial heating cycle \\
\hline P.R & Pressure ratio \\
\hline SRC & Simple regenerative cycle \\
\hline TIT & Turbine inlet temperature $(\mathrm{K})$ \\
\hline $\mathrm{S}-\mathrm{CO}_{2}$ & Supercritical carbon dioxide \\
\hline$T_{o}$ & Dead state temperature $(\mathrm{K})$ \\
\hline PPTD & Pinch point temperature difference (K) \\
\hline NY & Plant life (years) \\
\hline $\mathrm{OM}$ & Operation and maintenance cost (USD/kWe) \\
\hline$Q_{\text {in }}$ & Net heat recovered $(\mathrm{kW})$ \\
\hline$\eta_{I}$ & Energy efficiency (\%) \\
\hline$\eta_{I I}$ & Exergy efficiency (\%) \\
\hline VLE & Vapor liquid equilibrium \\
\hline$W_{\text {net }}$ & Power output $(\mathrm{kW})$ \\
\hline Recup & Recuperator \\
\hline C & Cost (MUSD) \\
\hline$x$ & Mass split ratio \\
\hline $\mathrm{amb}$ & Ambient \\
\hline cond & Condenser \\
\hline PVE & Present value of plant expenses (USD) \\
\hline tot & Total \\
\hline $\mathrm{t}$ & Turbine \\
\hline c & Compressor \\
\hline $\min$ & Minimum \\
\hline er & Operation and maintenance escalation rate $(\%)$ \\
\hline$u$ & Plant utilization factor $(\%)$ \\
\hline$r$ & Discount rate $(\%)$ \\
\hline $\mathrm{CF}$ & Cash flow \\
\hline $\mathrm{xp}$ & expenditure \\
\hline$T$ & Temperature (K) \\
\hline $\exp$ & Exponent \\
\hline $\mathrm{cr}$ & Critical \\
\hline
\end{tabular}

1, 2, 3 Numbers specifying various points in the power cycles 


\section{References}

1. Siddiqui, M.E.; Almitani, K.H. Proposal and Thermodynamic Assessment of S-CO $\mathrm{C}_{2}$ Brayton Cycle Layout for Improved Heat Recovery. Entropy 2020, 22, 305. [CrossRef]

2. Ahmadi, M.H.; Chau, K.-W.; Sadeghzadeh, M.; Pourfayaz, F.; Ghazvini, M.; Ming, T.; Meyer, J.P.; Sharifpur, M. Thermodynamic and economic analysis of performance evaluation of all the thermal power plants: A review. Energy Sci. Eng. 2019, 7, 30-65. [CrossRef]

3. Invernizzi, C.M.; Ayub, A.; Di Marcoberardino, G.; Iora, P. Pure and Hydrocarbon Binary Mixtures as Possible Alternatives Working Fluids to the Usual Organic Rankine Cycles Biomass Conversion Systems. Energies 2019, 12, 4140. [CrossRef]

4. Mohammadi, K.; McGowan, J.G. Thermoeconomic analysis of multi-stage recuperative Brayton cycles: Part II-Waste energy recovery using $\mathrm{CO}_{2}$ and organic Rankine power cycles. Energy Convers. Manag. 2019, 185, 920-934. [CrossRef]

5. Saghafifar, M.; Gadalla, M. A critical assessment of thermo-economic analyses of different air bottoming cycles for waste heat recovery. Int. J. Energy Res. 2018, 43, 1315-1341. [CrossRef]

6. Invernizzi, C.M.; Bonalumi, D. Thermal Stability of Organic Fluids for Organic Rankine Cycle Systems; Elsevier Ltd.: Amsterdam, The Netherlands, 2016.

7. Feher, E. The supercritical thermodynamic power cycle. Energy Convers. 1968, 8, 85-90. [CrossRef]

8. Dostal, V.; Driscoll, M.J.; Hejzlar, P. A Supercritical Carbon Dioxide Cycle for Next Generation Nuclear Reactors. Ph.D. Thesis, Massachusetts Institute of Technology, Cambridge, MA, USA, 2004.

9. Kulhánek, M.; Dostál, V. Thermodynamic Analysis and Comparison of Supercritical Carbon Dioxide Cycles. In Proceedings of the $\mathrm{SCCO}_{2}$ Power Cycle Symposium, Boulder, CO, USA, 24-25 May 2011; pp. 1-7.

10. Yoon, H.J.; Ahn, Y.; Lee, J.I.; Addad, Y. Potential advantages of coupling supercritical $\mathrm{CO}_{2}$ Brayton cycle to water cooled small and medium size reactor. Nucl. Eng. Des. 2012, 245, 223-232. [CrossRef]

11. Al-Sulaiman, F.A.; Atif, M. Performance comparison of different supercritical carbon dioxide Brayton cycles integrated with a solar power tower. Energy 2015, 82, 61-71. [CrossRef]

12. Wang, K.; He, Y.-L.; Zhu, H.-H. Integration between supercritical CO 2 Brayton cycles and molten salt solar power towers: A review and a comprehensive comparison of different cycle layouts. Appl. Energy 2017, 195, 819-836. [CrossRef]

13. Ayub, A.; Sheikh, N.A.; Tariq, R.; Khan, M.M.; Invernizzi, C.M. Exergetic optimization and comparison of combined gas turbine supercritical $\mathrm{CO}_{2}$ power cycles. J. Renew. Sustain. Energy 2018, 10, 044703. [CrossRef]

14. Manente, G.; Costa, M. On the Conceptual Design of Novel Supercritical $\mathrm{CO}_{2}$ Power Cycles for Waste Heat Recovery. Energies 2020, 13, 370. [CrossRef]

15. Kottek, M.; Grieser, J.; Beck, C.; Rudolf, B.; Rubel, F. World Map of the Köppen-Geiger climate classification updated. Meteorol. Z. 2006, 15, 259-263. [CrossRef]

16. Haroon, M. Thermodynamic Analysis of Bottoming Power Cycles Using Supercritical $\mathrm{CO}_{2}$-Based Binary Mixtures as Working Fluids; International Islamic University Islamabad: Islamabad, Pakistan, 2019.

17. Manzolini, G.; Binotti, M.; Bonalumi, D.; Invernizzi, C.; Iora, P. $\mathrm{CO}_{2}$ mixtures as innovative working fluid in power cycles applied to solar plants. Techno-economic assessment. Sol. Energy 2019, 181, 530-544. [CrossRef]

18. Invernizzi, C.M. Prospects of Mixtures as Working Fluids in Real-Gas Brayton Cycles. Energies 2017, 10, 1649. [CrossRef]

19. Invernizzi, C.M.; Van Der Stelt, T. Supercritical and real gas Brayton cycles operating with mixtures of carbon dioxide and hydrocarbons. Proc. Inst. Mech. Eng. Part A J. Power Energy 2012, 226, 682-693. [CrossRef]

20. Baik, S.; Lee, J.-I. Preliminary Study of Supercritical $\mathrm{CO}_{2}$ Mixed With Gases for Power Cycle in Warm Environments. In Proceedings of the ASME Turbo Expo 2018: Turbomachinery Technical Conference and Exposition, Lillestrøm, Norway, 11-15 June 2018.

21. Liu, X.; Xu, Z.; Xie, Y.; Yang, H. $\mathrm{CO}_{2}$-based mixture working fluids used for the dry-cooling supercritical Brayton cycle: Thermodynamic evaluation. Appl. Therm. Eng. 2019, 162, 114226. [CrossRef] 
22. Wu, C.; Wang, S.-S.; Jiang, X.; Li, J. Thermodynamic analysis and performance optimization of transcritical power cycles using $\mathrm{CO}_{2}$-based binary zeotropic mixtures as working fluids for geothermal power plants. Appl. Therm. Eng. 2017, 115, 292-304. [CrossRef]

23. Invernizzi, C.M.; Iora, P.; Manzolini, G.; Lasala, S. Thermal stability of n-pentane, cyclo-pentane and toluene as working fluids in organic Rankine engines. Appl. Therm. Eng. 2017, 121, 172-179. [CrossRef]

24. Di Marcoberardino, G.; Invernizzi, C.; Iora, P.; Ayub, A.; Di Bona, D.; Chiesa, P.; Binotti, M.; Manzolini, G. Experimental and analytical procedure for the characterization of innovative working fluids for power plants applications. Appl. Therm. Eng. 2020, 178, 115513. [CrossRef]

25. Ayub, A.; Invernizzi, C.M.; Di Marcoberardino, G.; Iora, P.; Manzolini, G. Carbon Dioxide Mixtures as Working Fluid for High-Temperature Heat Recovery: A Thermodynamic Comparison with Transcritical Organic Rankine Cycles. Energies 2020, 13, 4014. [CrossRef]

26. Haroon, M.; Ayub, A.; Sheikh, N.A.; Imran, M. Exergetic performance and comparative assessment of bottoming power cycles operating with carbon dioxide-based binary mixture as working fluid. Int. J. Energy Res. 2020, 44, 7957-7973. [CrossRef]

27. Xia, J.; Wang, J.; Zhang, G.; Lou, J.; Zhao, P.; Dai, Y. Thermo-economic analysis and comparative study of transcritical power cycles using $\mathrm{CO}_{2}$-based mixtures as working fluids. Appl. Therm. Eng. 2018, 144, 31-44. [CrossRef]

28. Yağlı, H.; Koç, A.; Karakus, C. Comparison of toluene and cyclohexane as a working fluid of an organic Rankine cycle used for reheat furnace waste heat recovery. Int. J. Exergy 2016, 19, 420-438. [CrossRef]

29. Görgülü, A.; Yağli, H.; Koç, Y.; Koç, A.; Baltacioğlu, E. Activated carbon adsorption behaviour of toluene at various temperatures and relative humidity. Environ. Prot. Eng. 2019, 45, 111-126. [CrossRef]

30. Span, R.; Wagner, W. A New Equation of State for Carbon Dioxide Covering the Fluid Region from the Triple-Point Temperature to $1100 \mathrm{~K}$ at Pressures up to 800 MPa. J. Phys. Chem. Ref. Data 1996, 25, 1509-1596. [CrossRef]

31. Yang, F.; Liu, Q.; Duan, Y.; Yang, Z. Crossover multiparameter equation of state: General procedure and demonstration with carbon dioxide. Fluid Phase Equilibria 2019, 494, 161-171. [CrossRef]

32. Lemmon, E.W.; Span, R. Short Fundamental Equations of State for 20 Industrial Fluids. J. Chem. Eng. Data 2006, 51, 785-850. [CrossRef]

33. Lopez-Echeverry, J.S.; Reif-Acherman, S.; Araujo-Lopez, E. Peng-Robinson equation of state: 40 years through cubics. Fluid Phase Equilibria 2017, 447, 39-71. [CrossRef]

34. Peng, D.-Y.; Robinson, D.B. A rigorous method for predicting the critical properties of multicomponent systems from an equation of state. AIChE J. 1977, 23, 137-144. [CrossRef]

35. Poling, B.E.; Prausnitz, J.M.; O'Connell, J.P. The Properties of Gases E Liquids, 5th ed.; McGraw-Hill Professional: New York City, NY, USA, 2001. [CrossRef]

36. Gas Turbine World 2013 GTW Handbook; Pequot publishing Inc.: Fairfield, CT, USA, 2013; pp. 1-126.

37. Sánchez Villafana, E.D.; Vargas Machuca Bueno, J.P. Thermoeconomic and environmental analysis and optimization of the supercritical $\mathrm{CO}_{2}$ cycle integration in a simple cycle power plant. Appl. Therm. Eng. 2019, 152, 1-12. [CrossRef]

38. Kim, M.S.; Ahn, Y.; Kim, B.; Lee, J.I. Study on the supercritical $\mathrm{CO}_{2}$ power cycles for landfill gas firing gas turbine bottoming cycle. Energy 2016, 111, 893-909. [CrossRef]

39. Aspen Technology Inc. Aspen Plus. The Chemical Industry's Leading Process Simulation Software; Aspen Technology Inc.: Bedford, MA, USA. Available online: https://www.aspentech.com/en/product s/engineering/aspen-plus (accessed on 28 September 2020).

40. Moran, M.J.; Shapiro, H.N.; Boettner, D.D.; Bailey, M. Fundamentals of Engineering Thermodynamics; John Wiley \& Sons: Hoboken, NJ, USA, 2010.

41. Marchionni, M.; Bianchi, G.; Tassou, S. Techno-economic assessment of Joule-Brayton cycle architectures for heat to power conversion from high-grade heat sources using $\mathrm{CO}_{2}$ in the supercritical state. Energy 2018, 148, 1140-1152. [CrossRef]

42. Ahmadi, P.; Dincer, I.; Rosen, M.A. Exergo-environmental analysis of an integrated organic Rankine cycle for trigeneration. Energy Convers. Manag. 2012, 64, 447-453. [CrossRef]

43. Dincer, I.; Ratlamwala, T.A.H. Thermodynamic Analysis. Available online: https://www.researchgate.net/p ublication/306303214_Thermodynamic_Analysis (accessed on 28 September 2020). 
44. US Department of Energy. U.S. Energy Information Administration, Independent Statistics \& Analysis. 2017. Available online: https://www.eia.gov/electricity/annual/html/epa_08_01.html (accessed on 24 April 2020).

45. Manente, G.; Fortuna, F.M. Supercritical $\mathrm{CO}_{2}$ power cycles for waste heat recovery: A systematic comparison between traditional and novel layouts with dual expansion. Energy Convers. Manag. 2019, 197, 111777. [CrossRef] 